\title{
REGIONAL DEVELOPMENT: THE IMPORTANCE OF THE INVOLVEMENT OF INHABITANTS AND INNOVATIVE APPROACHES IN MANAGEMENT
}

\author{
Dace ŠTeFenberga ${ }^{1}$, Biruta SlokA ${ }^{2}$
}

Ventspils University of Applied Sciences (Latvia), University of Latvia (Latvia)

\begin{abstract}
Innovation and an innovative approach in management, education and leadership have been changing over decades, according to the dynamic world we are living in. Changes start at an individual level, with the personality, and only those who have changed themselves can start to lead others towards global change.

The Latvian National Development Plan defined aspects of polycentric development for all the regions of Latvia. Each region has resources, strengths, weaknesses, opportunities and threats, but human resources are the most important resource for change, creative ideas and sustainable development. The education system changes very slowly, from lecture learning to a more inclusive 'learning by doing' approach. This approach has been used in northern countries for a while, but Latvia has just now started to implement the approach. The term 'innovation' today is wider than product, process, service or organisational innovation. At a national and regional level of development, it is crucial to encourage inhabitants of the region to stay in or return to rural areas, and create knowledge and enterprises in the region and their home town.

The aim of the paper is to evaluate the involvement of residents in management activities and regional development processes, and their willingness to participate in the creation of knowledge and innovative entrepreneurship and co-creation. The paper is a review of literature on theoretical aspects of the creation of innovation in the region in a combination of survey analyses of residents. The methodological approach is based on two steps: a review of research literature, and an analysis of the results of a survey of residents of the region of their willingness to be involved in processes and tasks for regional development, and some aspects of analysis of entrepreneur opinion about innovative solutions in their companies. The article consists of four main parts: 1) the theoretical findings of a systemic approach to innovation and development; 2) the role of the innovation process in development from different perspectives; 3) an analysis of a survey of the region's residents about their willingness to be involved in processes of regional development; 4) aspects of innovation used in regional entrepreneurship. The significance of the paper is to define aspects of regional development relating to innovation and co-creation.
\end{abstract}

KEY WORDS: innovation, regional development, knowledge, involvement.

JEL CODES: R10; M10; M11

DOI:

\section{Introduction}

The global, external environment is changing rapidly, and everyone has to take the right decisions in this VUCA world (volatility, uncertainty, complexity and ambiguity). A readiness to make changes should be at a high level, we have to make decisions today, based on the prospects of tomorrow, and enterprises which use new approaches guided by a source of the future, rather than repeating the models of the past, will be more successful and able to benefit society. We are living in a dynamic environment, where we somehow have to be able to overcome technologies and our addiction to them more and more: the permanent use of smartpho-

1 Dace Štefenberga - Ventspils University of Applied Sciences, Faculty of Economics and Management, Centre of Entrepreneurship, Innovation and Regional Development, Latvia e-mail: daces@venta.lv Tel.: +37126800288

2 Biruta Sloka - University of Latvia, Faculty of Business, Management and Economics, Latvia e-mail: biruta.sloka@lu.lv 
nes for different reasons, but more likely to stay connected, which means, if we are staying connected in the virtual world, at the same time we are less connected in face-to-face communication. This is a problem the new generation is facing: a lack or insufficiency of human communication. It is closely related to educational approaches used in institutions of higher education. The concept of Team Academy was coined in Finland more than 20 years ago in the higher education system. It consists of a 'learning by doing' approach, and starting a business during the study period; and a lot of decisions are made by 'teampreneurs' in communication through dialogue.

The style of management that is focused on the formulation of orders and the control of their execution, defining the goals and directions of development, is no longer viable. More and more importance should be given to seemingly secondary factors: both the methods of achieving the goals and the goals and priorities themselves change as a result of the dynamic environment (Sharmer 2018: 421).

Problem. Challenges identified in the Project of Guidelines for Regional Politics 2021-2027 is the highest level of regional differences among EU countries. The population of Latvia declined between 2010 and 2019 by more than 200,000. The existing problems in development are: the orientation towards a cheap labour business model more than the development of innovation, weak cooperation between industry and science, and monocentric regional development.

Purpose. The purpose of the article is to analyse both the impact of new approaches in learning about knowledge creation and the willingness of residents to participate in regional development processes.

Object. Innovation and the process of knowledge creation in the region through the involvement of inhabitants of the region.

Tasks: To analyse research literature on the role of knowledge creation and innovation in regional development; to analyse the results of a survey in 2015 and 2019 to understand the opinions of residents of the Kurzeme region about their possible participation in regional development processes.

Methods. A summary of research publications and previously conducted research results; a survey of inhabitants of the region; analytical methods in the analysis of survey data.

1. Theoretical findings in a systemic approach to knowledge, innovation and business education

The Central Bureau of Statistics of Latvia defines innovation as 'the implementation in practice of a new or fundamentally improved product (goods or service) or a new market method or organisational method' (Central Bureau of Statistics, 2018). The innovation concept and its definition and classification depend on implementation: a more important role in innovation definition gains a systemic and multi-dimensional approach (Andersson, Karlsson 2004: 22; Godin 2015: 326), researchers focus on cross-industry innovation capability and its systematism (Dosi, Grazzi, Moschella 2017: 421; Taalbi 2017: 1446). An interesting scientific discussion has started about innovation in historical development and its cycle by Godin (2015), as well as the importance of innovation to regional development (Godin 2015: 314; Boo, Abouzeedan, Hedner, Maack, Lundqvist 2013: 118). The essence of innovation is to recreate the world according to a particular ideal or vision (Nonaka, Takeuchi, 1995: 75). There are three characteristics of knowledge creation: 1) metaphor and analogy; 2) from personal to organisational knowledge; new knowledge always starts with an individual, an organisation cannot create knowledge on its own, without the knowledge of individuals; 3 ) ambiguity and redundancy, a source of alternate meaning, new knowledge grows out of chaos.

According to Kolb, Fröhlich, Schmidpeter (2017), universities are the main source of management education, and provide a link between knowledge creation and knowledge transfer in business structures and society (Kolb, Fröhlich, Schmidpeter 2017: 297). Professors and educational practitioners started to realise that cooperation through internships of students in business structures could boost more effective ways of learning. These were the development of the most effective cooperation models and the approbation of them. Academic research has paid a lot of attention to the analysis of scientific publications on Tripple Helix (Galvao, Mascarenhas, Marques, Ferreira, Ratten 2019: 821), as well as the importance of regional SME to re- 
gional development (Mason, Castleman, Parker (2008: 579), and the importance to the capacity for regional innovation (Carrillo, Schiuma, Lerro 2008: 132) and the organisational culture (Šimanskiene, Paužuoliene, Paužuolis 2015: 79).

Tripple Helix was the starting model (Etzkowitz 2011:158; Leydesdorff 2005: 29), continuing to Quadruple Helix (Arnkil 2010: 124), and today Penta Helix (Ostrom 2010: 668; Calzada 2017: 26). The most important part of Penta Helix is social entrepreneurship and the involvement of society. What kind of cooperation will follow? This approach is about to reconfigure the role of education and universities, and demands new ways of thinking and the creation and acquisition of knowledge in business education, to emphasise the 'learning by doing' approach (Partanen 2017: 119). A company carries it out when it develops an innovative idea in the market. These include the formation of interest groups, or clustering, networking, the openness of ideas, education (higher, technological), creativity, and knowledge formation. At this level of cooperation, the most important tasks include the development of creativity and knowledge-building. According to Partanen (2017), there are three ways of learning: 1) individual learning (self-leadership-information acquisition); 2) team learning (the learning process in teams, and also in the discussion and reflection of books); and 3) team company learning (learning through real business situations) (Partanen 2017: 103). According to Uldis Pīlēns (2019), a company owner and entrepreneur for several decades, innovation could also be by using non-traditional methods in the usual environment at the right time. He has also stressed that in moments of crisis, entrepreneurs usually start to become innovators: 'Troubles and problems are the mothers of innovation' (Pîlēns 2019:276). The Japanese intellectual tradition has defined three aspects: 1) the oneness of humanity and nature; 2) the oneness of body and mind (the whole personality); 3) the oneness of the self and the other (Nonaka, Takeuchi 1995: 176), in addition to other important factors. Nowadays, we are thinking more and more about how to embody these three aspects in everyday life at the individual and organisational level.

\section{The role of involvement in processes in the development of the region}

We can define two main levels in how we organise our life and work, balancing and taking decisions. The first is an individual level, where all my own personality aspects are, what Robin Sharma defines in four ways: mindset, heart set, soul set, health set; and the second is at an institutional level, where we start to act like institutions (Sharma, 2019: 75). At the individual level, the entrepreneur can also be alone and create his own idea, but it is important for him first to answer the question 'Why?', and inspire others to believe in the idea and help drive it with the same enthusiasm (Sinek, 2009: 17). In this local institutional environment, our organisation includes institutional-individual level aspects that work in a dynamic environment with a set of environmental factors that can be grouped according to type of impact: the legal, ecological, technological, social, economic and political environment, constantly changing their influence, form a set of external environmental factors, which influence the individual-institutional level at every moment in time. The impact of individual factors can be predicted, but as a result of the continuous interaction of factors, the ability to predict the overall result decreases.

The governmental programme 'EKOSOC_LV' was organised in Latvia between 2014 and 2018. Ventspils University of Applied Sciences, the University of Latvia and other universities and public institutions participated in this governmental research programme, in order to define scenarios for inclusive regional development. The authors of this publication participated in projects in the research programme, and carried out a survey in the Kurzeme region. The questionnaire in the project included three sets of questions, relating to the evaluation of: 1) the state as an institution; 2) local government institutions; 3) local communities, the readiness of inhabitants for involvement in local government processes. Another governmental programme project 'Challenges to the Latvian State and Society and the Solutions in an International Context (INTERFRAME-LV)' has been going since 2019, and is still in progress. The same questionnaire was used in this programme. The results for the years 2015 and 2019 are presented in this paper. 


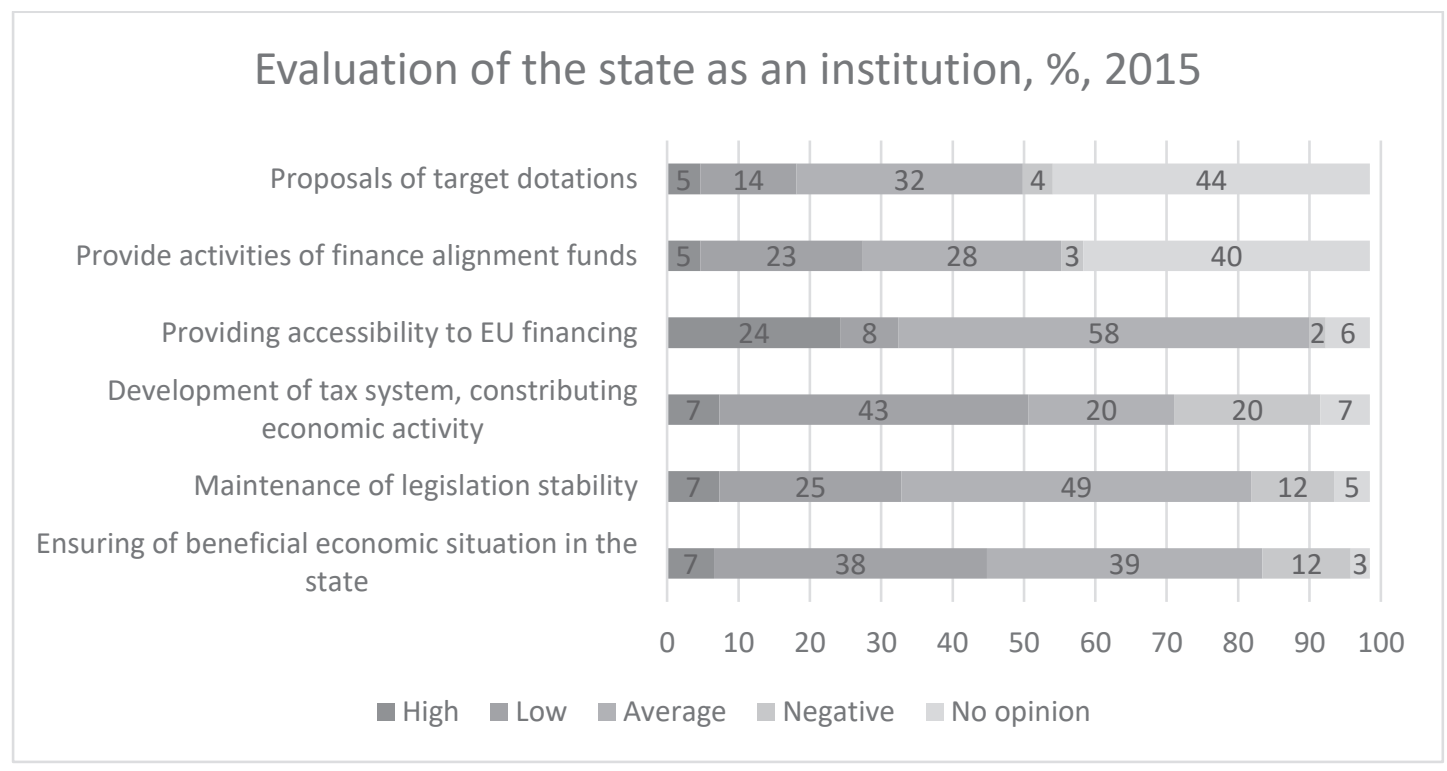

Figure 1. Evaluation of the state as an institution, 2015, n=259.

Source: Author's construction based on research.

The research results show that residents of the region distinguish the most visible impact of the state as an institution in providing accessibility to EU funding. The stability of legislation is very important for residents, including entrepreneurs. Unfortunately, legislation changes very frequently, and people are not able to cope with these changes. Residents consider the national policy of the tax system in promoting economic activity to be very low and negative. Respondents did not have a strong opinion of target subsidiary and the activities of finance alignment funds. According to the results, the high evaluation of the impact of the state as an institution did not exceed $7 \%$, which might show a tendency as to how the residents of the region evaluate state institutions overall.

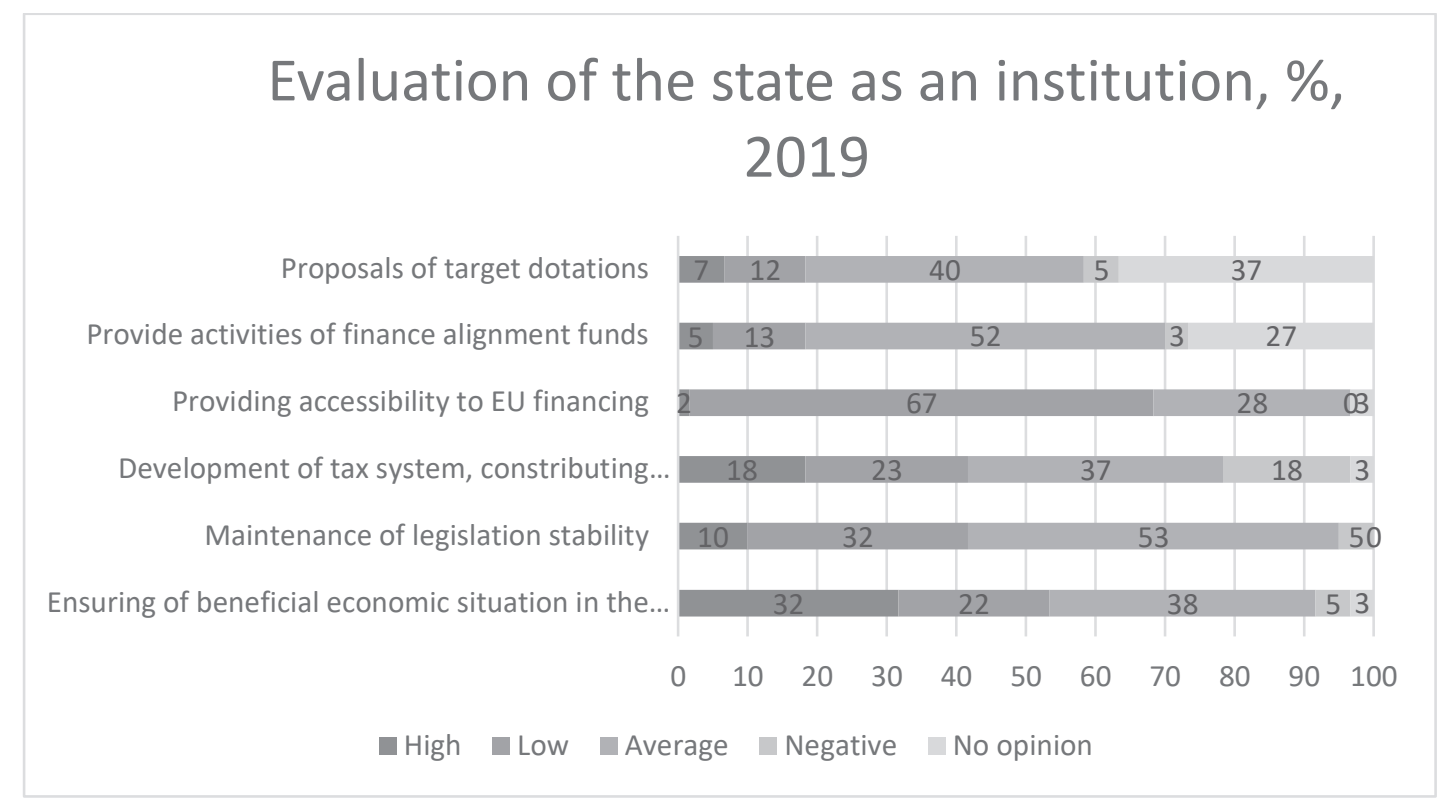

Figure 2. Evaluation of the state as an institution, 2019, n=104.

Source: Author's construction based on research. 
The rise in the high evaluation of the state as an institution in the factor 'Ensuring a beneficial economic situation in the state' is quite surprising, but in 2019 this result exceeded by four times the results of 2015. It is a good sign that tenants are starting to believe in activities organised by state institutions. A different opinion is expressed on providing accessibility to EU funding, which means that there is dissatisfaction with the assistance from state institutions, especially those responsible for communications in EU project implementation processes. Residents have no formulated opinion about questions relating to targeted subsidy, which can be explained by the lack of interest in these issues.

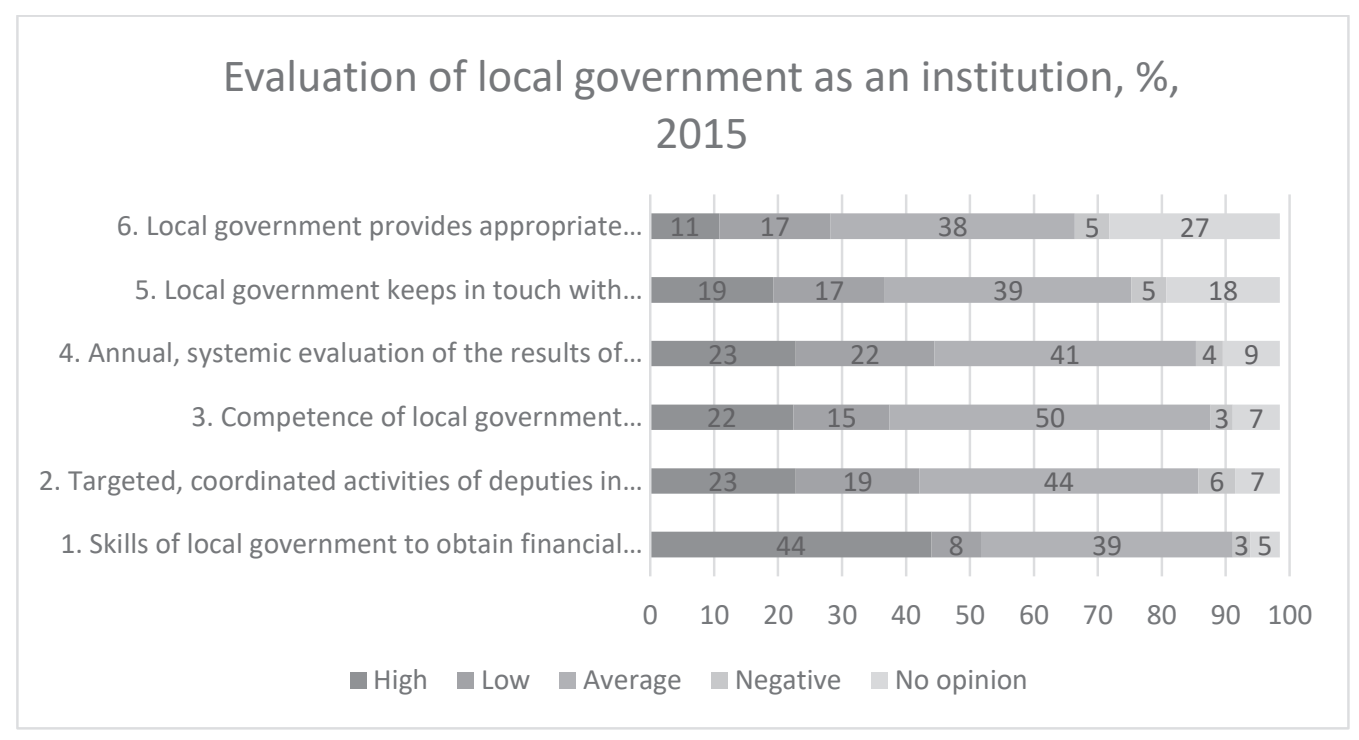

Figure 3. Evaluation of local government as an institution, 2015, n=259.

Source: Author's construction based on research.

The skills of local government institutions in attracting financing from EU funds, their use and the competence of the staff of local government institutions in planning processes and project management were evaluated at the highest level by residents of the region. The evaluation for targeted, coordinated activities by deputies in the development and implementation of strategies for the local community is also very positive. Most answered 'No opinion' to questions about the conditions, what local government provides to NGOs and other society group activities, and their involvement in discussions and the realisation of important development issues. The increasing involvement of residents may improve the results of common work, and improve the opinions of residents on their collaboration and involvement in processes.

Local government institutions in the Kurzeme region were evaluated with this set of questions. The results of the evaluation of local government institutions in the year 2019 were quite similar to previous results. The skills of local government in obtaining financial resources from EU structural funds are evaluated at a positive level; there are no negative answers at all. The evaluation of local government institutions for the annual, systemic analysis of local development strategies and decision making based on these documents is also high. The competence of representatives of local government in regional development are evaluated more as average, but $37 \%$ also as high. From experience, there is a very strong culture of project development and the development of long-term documents for regional prosperity in local government. The respondents were residents of the Kurzeme region, especially the city of Ventspils; so it was very important for them. Maybe the results would be different if most respondents came from rural areas only. Most respondents worked in Ventspils but lived in rural areas of the Kurzeme region, in Pope, Ugāle, Piltene and Ance, and even in Kuldīga, Talsi and the areas around them. Local government is at an institutional level, but smaller and closer to the residents of the region, and therefore feedback from institutional activities is more relevant than at a state level. 


\section{Evaluation of local government structures, \%, 2019}

6. Local government provides appropriate conditions for NGO's and other society group activities, and...

5. Local government keeps in touch with entrepreneurs in solving tasks, essentials for both..

4. Annual, systemic evaluation of the results of implementation of development strategies and..

3. Competence of local government representatives in region development planning and project...

2. Targeted, coordinated activities of deputies in development and implementation of territory...

1. Skills of local government to obtain financial resources of EU structural funds

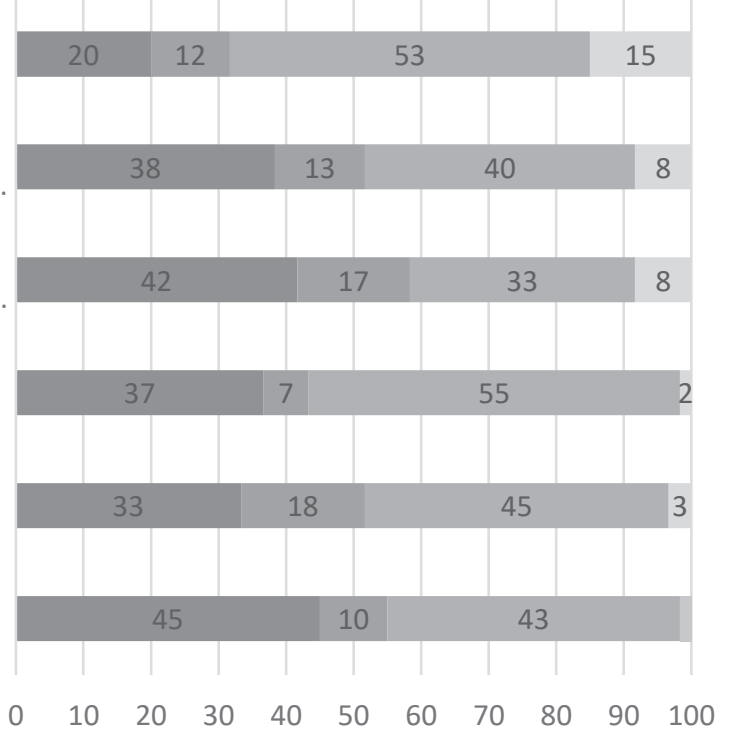

- High $\square$ Low Average Negative $\square$ No opinion

Figure 4. Evaluation of local government as an institution, 2019, n=104.

Source: Author's construction based on research.

\section{Evaluation of the local community, \%, 2015}

6. Visible readiness to accept changes in work, society, external environment

5. Tenants of region cooperating not only in activities, related to sports and culture, but in... 4. Readiness of tenants to get new knowledge, in participation of lectures, seminars and life-long... 3. Activities of tenant groups for acquisition and dissemination of innovative ideas

2. Readiness of local tenants for economic activities in order to rise self incomes

1. Wish of local tenants to participate in solving tasks of local government in active cooperation...
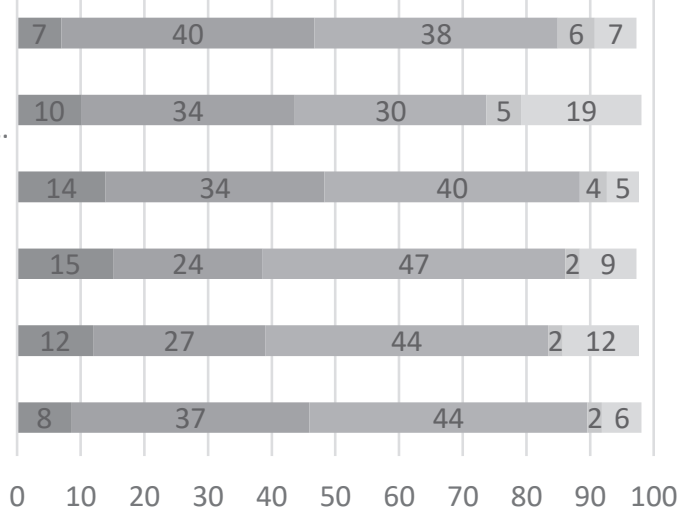

High Low Average Negative No opinion

Figure 5. Evaluation of the local community as an institution, 2015, n=259.

Source: Author's construction based on research.

Residents evaluate as very low the readiness of the local community (and at the same time, their own readiness) to participate in practical decision-making processes and take action to increase the well-being of the local community, and also to accept changes in work, society, and the local environment. 


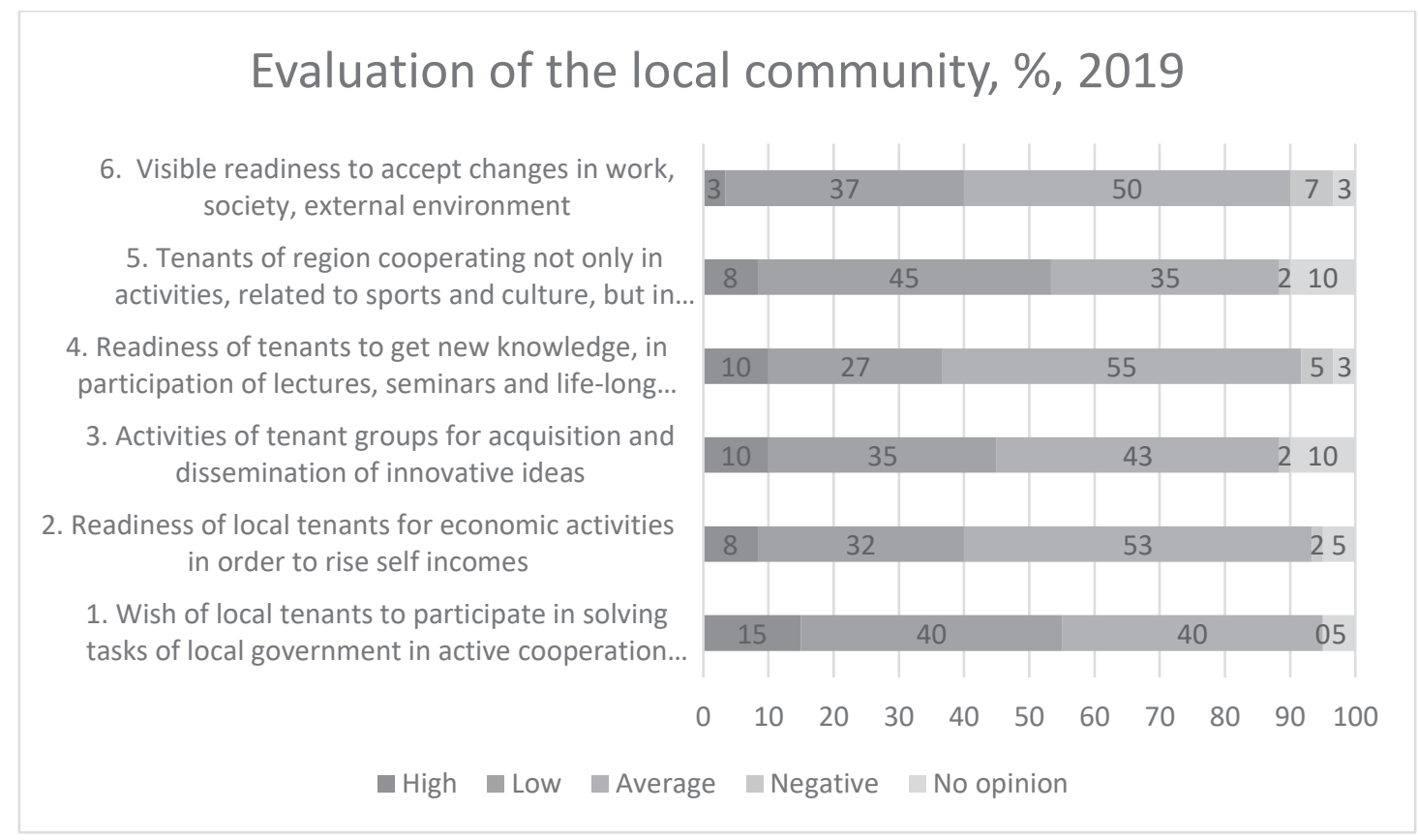

Figure 6. Evaluation of the local community as an institution, 2019, $n=104$.

Source: Author's construction based on research.

More than $40 \%$ evaluated as very low the readiness of the local community (including themselves as a part of the local community) to participate in economic activity and even increase personal income. This aspect shows processes in the local community from the perspective of residents. The problem is somehow even much deeper, because employee burn-out, the disinclination to work in industry, having no wish to 'flash-about' one's idea, are relevant to the results of enterprises, and also to public institutions in general. Performance at an individual level reflects in results and performance at an institutional level. In the results for 2019, we can see tendencies that a high evaluation of the local community to participate in local processes declined in all questions, and even in the willingness to cooperate with other residents in the local community.

\section{Conclusions}

The results of the evaluation of state-level institutional organisations could be defined from average to very low, especially in providing accessibility to EU funding.

The results show that local government organisations can create networks of entrepreneurship with local enterprises, in order to solve the challenges of the participants involved. Local government organisations in these three question groups were evaluated at the highest level in comparison with state-level institutions and local communities themselves.

The results show that there is also a very low desire among residents to acquire new knowledge and skills, and participate in study programmes and study courses in the Kurzeme region. Nevertheless, residents feel the wish to cooperate with local government institutions and local communities in order to increase economic activity and incomes. Possible solutions could be interest groups and information channels for different activities through social networks. There is evidence of other incentives, especially from youth, that they are starting to act and participate in different idea-generation studies, usually formed in the local community, and the local community is the only place to come together with others, and try to balance work, study and personal development tasks, in order to become high-potential players. Regional knowledge centres, like universities and higher education and research institutions, in cooperation with local NGOs, municipalities and business support structures, can initiate and realise changes in the transformation process of residents. 
One aspect of regional development is to use regional natural resources in the highest-potential and most responsible way, setting appropriate strategic goals for the region.

\section{References}

Arnkil, R., Jarvensivu, A., Koski, P., Piirainen, T. (2010) Exploring Quadruple Helix. Outlining User Oriented Innovation Mode. Tampere: University of Tampere. Available at https://pdfs.semanticscholar.org/1b05/707103533bcc3b8 6bf13105a2e443ab9ba69

Boo, E., Abouzeedan, A., Hedner, T., Maack, K., Lundqvist, M. (2013). Using scenario planning in regional development context: the challenges and opportunities. World Journal of Science, Technology and Sustainable Development, Vol. 10, No. 2, p. 103-122.

Calzada, I., Cowie, P. (2017). Beyond Smart and Data-Driven City-Regions? Rethinking Stakeholder- Helixes Strategies. Regions Magazine, Vol. 308, No. 4, p. 23-28.

Central Bureau of Statistics in Latvia. (2018). Definitions. Available at https://www.csb.gov.lv/lv/statistika/statistikastemas/ ekonomika

Carrillo, F., Schiuma, G., Lerro, A. (2008). Knowledge-based capital in building regional innovation capacity. Journal of Knowledge Management, Vol. 12, No. 5, p. 121-136.

Crescenzi, R., Filipetti, A., Iammarino, S. (2017). Academic Inventors: Collaboration and Proximity with Industry. Journal of Technology Transfer, Vol. 42, No. 4, p. 730-762.

Dosi, G., Grazzi, M., Moschella, D. (2017). What do firms know? What do they produce? A new look at the relationship between patenting profiles and patterns of product diversification. Small Business Economics, Vol. 48, No. 2, p. $413-429$.

Etzkowitz, H. (2011). The Triple Helix: university - industry - government innovation in action. Sweden: Science Policy Institute.

Fini, R., Grimaldi, R., Santoni, S., Sobrero, M. (2011). Complements or substitutes? The role of Universities and Local context in supporting the creation of academic spin-offs. Research Policy, Vol. 40, No. 8. p. 1113-1127.

Galvao, A., Mascarenhas, C., Marques, C., Ferreira, J., Ratten, V. (2019). Triple helix and its evolution: a systematic literature review. Journal of Science and Technology Policy Management, Vol. 10, No. 3, p. 812-833.

Godin, B. (2015). Innovation Contested the Idea of Innovation Over the Centuries. London: Routledge.

Griffin, R. W. (1999). Management. Sixth Edition. Boston, New York: Houghton Mifflin Company.

Kolb, M., Fröhlich, L., Schmidpeter, R. (2017). Implementing sustainability as the new normal: Responsible management education - from a private business school's perspective. International Journal of Management Education, Vol. 15, No. 2, p. 280-292.

Leydesdorff, L. (2011). The Tripple Helix, Quadruple Helix, ..., and an N-Tuple of Helices: Explanatory Models for Analyzing the Knowledge Based Economy. Journal of Knowledge Based Economy, Vol. 3, No. 1, p. 25-35.

Mason, C., Castleman, T., Parker, C. (2008). Communities of enterprise: developing regional SMEs in the knowledge economy. Journal of Enterprise Information Management, Vol. 21, No. 6, p. 571-584.

Nonaka, I., Takeuchi, H. (1995) The Knowledge Creating Company. Howe Japanese Companies Create the Dynamics of Innovation. Oxford University Press.

Ostrom, E. (2010). Beyond Markets and States: Polycentric Governance of Complex Economic Systems. American Economic Review, Vol. 100, No. 3, p. 641-672.

Partanen, J. (2017). The Team Coach's Best Tool. Finland: Tiimiakatemia.

Pīlēns, U. (2019). (Mans) uznēemēja kods. [(My) code of entrepreneur]. Rīga: Zvaigzne ABC.

Sentana, E., Gonzalez, R., Gasco, J., Llopis, J. (2017). The social profitability of business incubators: a measurement proposal. Entrepreneurship and Regional Development, Vol. 29, No. 1-2, p. 116-136.

Sinek, S. (2009). Start with why. How great leaders inspire everyone to take action. Penguin Group: USA.

Sharma, R. (2018) The 5am Club: Own Your Morning. Elevate Your Life. Harper Collins Publishers.

Shepard, J. M. (2017). When incubators evolve: New Models to assist innovative entrepreneurs. Entrepreneurship and Regional Development, Vol. 29, No. 1-2, p. 116-136.

Šarmers, K. O. (2018). U teorija. Vadība no topošās nākotnes. [U theory. Management from emerging future]. Rīga: Zvaigzne ABC.

Šimanskiene, L., Paužuoliene, J., Paužuolis, V. (2015). Characteristics of Innovative Organizational Culture in Small and Medium Enterprises. Management of Organizations: Systematic Research, Vol. 73, p. 63-81.

Taalbi, J. (2017). What Drives Innovation? Evidence from Economic History. Research Policy, Vol. 46, No. 8, p. 1437-1453.

VARAM. (2019). Project of guidelines for regional politics of Latvia 2021-2027. 


\title{
REGIONO PLËTRA: GYVENTOJUZITRAUKIMO SVARBA IR INOVATYVUS VADYBINIS POŽI Ü IS
}

\author{
Dace Štefenberga, Biruta Sloka \\ Venspilio kolegija, Latvijos universitetas (Latvija)
}

\section{Santrauka}

Inovacijos, naujas požiūris ị vadybą, švietimą ir lyderystę kito dešimtmečiais, atsižvelgiant ị pasaulio, kuriame gyvename, dinamiškumą. Pokyčiai prasideda nuo individualaus lygmens - asmenybės. Tik tie, kurie pasikeitè, gali vesti kitus link globalių pokyčių.

Latvijos nacionaliniame plètros plane apibrèžti policentrinès plètros aspektai visuose Latvijos regionuose. Kiekvienas regionas turi tam tikrų išteklių, savo stipriąsias ir silpnąsias puses, galimybes ir grèsmes, pažymėtina, kad būtent žmogiškieji ištekliai yra svarbiausi kūrybinių idejjų, kurios lemia pokyčius ir darnų vystymosi, ištekliai. Švietimo sistema nuo mokymosi per paskaitas prie įtraukaus „,mokymosi darant“ požiūrio kinta gana lètai. Šis metodas, kurị laiką jau taikomas Šiaurès šalyse, pamažu pradedamas taikyti ir Latvijoje. Jis glaudžiai susijęs su inovacijos terminu, nes tenka keisti mąstymą ir mokytis taikant naujus metodus. Siekiant vystymosi nacionaliniu ir regioniniu lygmenimis, svarbu skatinti regiono gyventojus likti ar grižti ị kaimo vietoves ir čia kurti įmones.

Straipsnyje siekta ịvertinti gyventojų įsitraukimą ị vadybos ir regionų plètros procesą, norą dalyvauti bendrame kūrybiniame procese, kuriant žinias ir inovatyvujį verslumą. Straipsnio pobūdis - literatūros apžvalga, paremta teoriniais inovacijų kūrimo regione aspektais, derinant gyventojų apklausų analizę. Metodologinis požiūris grindžiamas dviem etapais: mokslinès literatūros apžvalga ir regiono gyventojų apklausos, kiek jie nori įsitraukti ị regiono pletros procesus bei užduotis, verslininkų nuomonių apie novatoriškus sprendimus savo įmonèse, rezultatų analizè. Straipsnị sudaro: 1) sisteminio inovacijų ir plètros požiūrio teorinès išvados; 2) inovacijų proceso vaidmuo plètojant ịvairias perspektyvas; 3) regiono gyventojų apklausos, kiek jie nori ịsitraukti ị regionų plètros procesus, rezultatų analizé; 4) regioninio verslumo inovacijų aspektai. Straipsnyje siekiama apibrěžti regionų plètros aspektus, kurie susiję su inovacijomis ir bendruoju kūrybiškumu.

Tyrimo rezultatai atskleide, kad vietos valdžios organizacijos geba kurti verslumo tinklus su vietos ịmonėmis, siekdamos spręsti dalyvaujančiụjų problemas. Vietos valdžios organizacijos tyrimų rezultatai ịvertinti aukščiausiais balais, palyginti su valstybinèmis institucijomis ir vietos bendruomenèmis. Rezultatai atskleidè, kad gyventojai nelabai siekia ịgyti naujų žinių, igūdžių, dalyvauti studijų programose, studijų kursuose Kuržemès regione, nors ir nori bendradarbiauti su vietos valdžios institucijomis bei vietos bendruomenėmis, kad padidètų pajamos iš jų veiklos. Vienas iš regioninès plètros aspektų - atsakingesnis regioniniu gamtos išteklių naudojimas ir tinkamų strateginių regiono tikslų nustatymas.

PAGRINDINIAI ŽODŽIAI: inovacijos, regionu plètra, žinios, dalyvavimas.

JEL KLASIFIKACIJA: R10; M10; M11

Received: 2019-12-15

Revised: 2020-01-15

Accepted: 2020-01-30 